\title{
Mouthwashes and Nasal Sprays as a Way to Prevent the Spread of SARS-CoV-2
}

\author{
Enjuagues Bucales y Aerosoles Nasales como un \\ Método de Prevenir la Propagación de SARS-CoV-2
}

\author{
Matías Santos-López'; Diego Jaque'; Edgardo Fuentes² \& David González-Quintanilla²
}

SANTOS-LÓPEZ, M.; JAQUE, D.; FUENTES, E. \& GONZÁLEZ-QUINTANILLA, D. Mouthwashes and nasal sprays as a way to prevent the spread of SARS-CoV-2. Int. J. Odontostomat., 14(4):513-518, 2020.

\begin{abstract}
COVID-19 pandemic has infected millions of people around the world. Due to its large accumulation in the nasopharyngeal region and transmission through respiratory fluids, its spread among people is extremely high. Considering the needed time for treatments and vaccine development, the research of preventive methods, such as the use of mouthwash and nasal spray, that could decrease the viral load in the nasopharyngeal region, and thus the spread of SARS-CoV-2, becomes fundamental. The evidence has shown that there are compounds with antiviral capacity that could be used for this purpose, among which are povidone-iodine, hydrogen peroxide, cyclodextrins, and the synthetic drug PUL-042. Currently, there is no clinical evidence that proves the effectiveness of these substances against SARS-CoV-2. Nevertheless, there are ongoing clinical trials to prove it and generate methods that could help to prevent or, at least, decrease its spread among the population and stop this pandemic.
\end{abstract}

KEYWORDS: SARS-CoV-2, COVID-19, Mouthwashes, Nasal sprays, prevention.

\section{INTRODUCTION}

In December 2019, medical centers in Huanan, China, reported multiple cases of atypical pneumonia, with an etiologic agent unknown until then. The outbreak was linked to the Huanan Seafood Wholesale Market, warning of a possible zoonotic origin of the disease (Lake, 2020; Zhu et al., 2020). In January 2020, the China Center for Disease Control and Prevention (China CDC) announced the discovery of a new coronavirus type, named COVID-19, to which the outbreak in December was attributed (Meng et al., 2020). On January 31st, 2020, after the exponential increase in cases around the world, the World Health Organization (WHO) declared the Severe Acute Respiratory Syndrome virus (officially named as SARSCoV-2) and its disease COVID-19 as a pandemic (Mahase, 2020).

Until June 06, 2020, SARS-CoV-2 had infected $6,855,858$ people in 187 countries, killing 398,321 of them (Johns Hopkins University \& Medicine, 2020).
SARS-CoV-2. SARS-CoV-2 is a positive-sense singlestranded RNA virus, part of the beta coronaviruses family (Cheng \& Shan, 2020). Phylogenetically is 97 $\%$ related to bats coronavirus, $79 \%$ to the Severe Acute Respiratory Syndrome coronavirus (SARS-CoV), and $50 \%$ to the Middle East Respiratory Syndrome coronavirus (MERS-CoV) (Lu et al., 2020; Zhou et al., 2020; Perlman, 2020).

A zoonotic origin is considered, transmitted by consumption of wild animals that host it (Perlman), and then, between humans by close contact or through respiratory secretions (Rothan \& Byrareddy, 2020; Chan et al., 2020; Phelan et al., 2020; Jin et al., 2020). The median incubation period varies between 4 and 5.2 days, with a range between 0 and 24 days (Rothan \& Byrareddy; Guan et al., 2020; Li et al., 2020; Wang et al., 2020a).

SARS-CoV-2 infects host cells, through the spike protein, which binds to cellular ACE2 receptors

\footnotetext{
${ }^{1}$ Faculty of Dentistry, Universidad Finis Terrae, Chile.

${ }^{2}$ Faculty of Health Sciences, Universidad Autónoma de Chile, Chile.
} 
(Hoffmann et al., 2020; Wan et al., 2020; Verdecchia et al., 2020). After infection, the patient develops symptoms that can range from mild to severe (Wu et al., 2020). Among the mild symptoms, fever, dry cough, and dyspnea are reported as the most common (Huang et al., 2020), in addition to headaches, vomiting, and diarrhea. In the most severe conditions, patients develop pneumonia, increased pro-inflammatory cytokines, respiratory failure, and finally, multi-organ failure (Rothan \& Byrareddy; Yuki et al., 2020; Shi et al., 2020; Guan et al.).

Different types of treatments are currently being investigated, mainly with antivirals such as remdesivir, lopinavir, ritonavir, and oseltamivir, and drugs combinations such as hydroxychloroquine and azithromycin (Lai et al., 2020; Amanat \& Kramer, 2020; Wang et al., 2020b; González-Quintanilla \& SantosLópez, 2020; Gautret et al., 2020; Cao et al., 2020). According to researchers, a vaccine could be available in 12-18 months (Amanat \& Kramer).

Mouthwashes and nasal sprays. SARS-CoV-2 presents tropism to different human tissues (Chu et al., 2020). The epithelial cells of the intestine, cornea, and respiratory structures are the main affected since they express specific receptors such as ACE2 and TMPRSS2, which allow the entry of the virus (Sungnak et al., 2020). Furthermore, high expression of ACE2 was demonstrated in ciliated cells and mucus of the nasal cavity, which explains the ease of transmission of SARSCoV-2. When analyzing the viral load in symptomatic and asymptomatic patients infected with SARS-CoV-2, it is shown that greater load is found in the nasopharyngeal región (Pan et al., 2020; Zou et al., 2020).

While several studies are currently underway to develop treatments and vaccines, few are focused on nasopharyngeal region intervention (Felsenstein et al., 2020). According to the evidence, among the compounds with antiviral capacity, what could be safe to use in contact with mucosa are povidone-iodine, hydrogen peroxide, modified cyclodextrins and PUL-042, a synthetic inhalation drug (Eggers et al., 2018; Kampf et al., 2020; Carrouel et al., 2020; Leiva-Juarez et al., 2018).

The development of mouthwashes or nasal sprays that could decrease the viral load of SARS-CoV2 in the nasopharyngeal region, in addition to preventing contact, contributes as a prophylactic tool for high exposure during medical attention, such as endotracheal intubations or dental care in general.
Povidone iodine (PVP-I). The PVP-I is a widely used antimicrobial, thanks to its capacity to penetrate the microorganism and oxidize its nuclear structures (Kawana et al., 1997). Evaluations in vitro of the effectiveness of the PVP-I to inactivate SARS-CoV show that the exposition to it for 2 minutes reduces the infectivity from the virus, taking it to undetectable levels (Kariwa et al., 2006).

Besides, it has been analyzed in vitro the efficacy of different formulations of PVP-I against MERS-CoV, among them, a mouthwash. It has been concluded that in a $1 \%$ concentration applied for 30 seconds, it reduces the viral charge (Eggers et al., 2015).

It has been investigated in vitro the virucidal effect of a mouthwash with PVP-I at $7 \%$, diluted 1:30 in water, formulating a $0.23 \%$ concentration, recommended for human use. It has been concluded that after 15 seconds of exposition, it succeeded in inactivating some pathogens like influenza virus $A$ (H1N1), SARS-CoV and MERS-CoV (Eggers et al., 2018).

Thus, its usage could be considered safe for the nasopharyngeal region, and efficient to reduce the presence of SARS-CoV-2.

Until now has not been clinically demonstrated the safety and effectiveness of a mouthwash or nasal spray made of PVP-I in the reduction of the SARSCoV-2 charge in the nasopharyngeal region, but considering all the conclusions from previous studies, researchers suggest a protocol of use for health workers and infected patients, based on using a mouthwash with PVP-1 at $0.5 \%$ for 30 seconds every 6 hours, and nostrils wash, with a $0,3 \mathrm{ml}$ syringe with PVP-I at 0.5 \% (Kirk-Bayley et al., 2020).

At present, researchers are developing three clinical studies, which are evaluating the efficiency and safety of the mouthwash and nasal spray made of PVP-I in the reduction of the SARS-CoV-2 charge.

The first one, which is in a phase II trial, endeavors to compare the efficacy of the mouthwash and the nasal wash of PVP-I at $0,5 \%, 0,12 \%$ chlorhexidine and a saline solution, under the hypothesis that 4 daily applications would reduce SARS-CoV-2 viral charge in the nasopharynx, improving the clinical symptoms of the patients and decreasing the chances of contagion (Rickert, 2020). 
The second one, also in phase II, is aimed at determining the safety and efficacy of the nasal sprays made of PVP-I at $0.5 \%$ and $0.9 \% \mathrm{Vs}$ an isotonic solution at $0.9 \%$, in patients infected with SARS-CoV2 , under the hypothesis that the mouthwash with PVPI would decrease the viral charge of SARS-CoV-2 (Nayak \& Vukkdala, 2020).

The third and last study, in phase II, is evaluating the efficacy of a mouthwash and a nasal spray made of PVP-I at $10 \%$, diluted 1:30 in water, used prophylactically in health workers who have not been infected, comparing it with a group of health workers who are not using the mouthwash and nasal spray (Kejner, 2020).

Hydrogen peroxide $\left(\mathrm{H}_{2} \mathrm{O}_{2}\right)$. The $\mathrm{H}_{2} \mathrm{O}_{2}$ has an antimicrobial effect, which oxidizes the cell structures, damaging the cell wall and its interior composition (Finnegan et al., 2010). It has been evaluated the capacity of the $\mathrm{H}_{2} \mathrm{O}_{2}$ to inactivate different types of coronavirus like MERS-CoV, SARS-CoV and HCoV, concluding that the $\mathrm{H}_{2} \mathrm{O}_{2}$ at $0.5 \%$ for 1 minute is effective to inactive them in inert surfaces (Kampf et al.)

Despite its antimicrobial properties, the evidence is not conclusive about the safety of the $\mathrm{H}_{2} \mathrm{O}_{2}$ in contact with mucous. Some researchers have associated it with abnormalities of the oral mucosa and have not recommended its use (Tombes \& Gallucci, 1993) although others affirmed that in a $1.5 \%$ concentration, it could be safe and effective to decrease the bacterial charge (Sharma et al., 2019).

Recent studies mention that the mucous would stay unaltered after being treated with $\mathrm{H}_{2} \mathrm{O}_{2}$ at $3 \%$ in 10 volumes, and that is why they propose its use under a protocol of mouthwash 3 times a day and a nebulizer for nasal wash twice a day. This protocol could be effective to reduce the viral charge and improve symptoms of the infected patients (Caruso et al., 2020). It has to be affirmed that there is no clinical studies that can check the effectiveness of the $\mathrm{H}_{2} \mathrm{O}_{2}$ as a mouthwash or nasal spray in the reduction of the viral charge in the nasopharynx. However, one is being developed in phase II to determine its effectivity on infected patients, with a formulation at $1 \%$, for 20 to 30 seconds, 3 times a day, for 6 days (Kazmi, 2020).

Cyclodextrins. Cyclodextrins (CD) are natural derivatives of glucose (Jambhekar \& Breen, 2016), with broad advantages compared to other oral care product compounds. They present greater biocompatibility, greater simplicity to use, and they do not generate a resistance reaction and are not toxic (Kurkov \& Loftsson, 2013). CDs attract a virus with the purpose of irreversibly inactivate it, altering its outer layer and destroying infected particles by simple contact, instead of blocking viral growth (Carrouel et al.).

Methylated beta-cyclodextrin has been found to reduce the influenza A virus and the infectivity of some coronaviruses by sequestering cholesterol from viral particles or depleting it from host cell membranes (Pratelli \& Colao, 2015). Therefore, the use of CDs in mouthwash and nasal sprays, together with oxidizing agents such as Citrox® (an antimicrobial with oxidizing activity against bacteria, fungi, and viruses) (Tait et al., 2006), may reduce viral load and transport of SARSCoV-2 (Carrouel et al.; Zhang \& Liu, 2020; González \& Santos-López, 2020).

Currently, there are no clinical studies that verify the effect of cyclodextrins against SARS-CoV-2.

PUL-042. PUL-042 is a synthetic ligand-based inhalation drug for TLR: Pam2CSK4 acetate (Pam2), a synthetic diacylated lipopeptide that is an agonist for TLR2 and TLR6, and the TLR9 agonist oligodeoxynucleotide. At the level of respiratory epithelial cells, it stimulates the production of peptides and reactive oxygen species against pathogens, including bacteria, fungi, and viruses (Broom \& Scott, 2020).

To date, early findings indicate that it has provided antiviral protection in animal models and, together with oseltamivir, protection against different types of influenza viruses (Leiva-Juarez et al.)

A phase II clinical trial is currently underway to determine the effectiveness of a PUL-042 inhalation solution in reducing the spread and progression of SARS-CoV-2 (Broom \& Scott, 2020).

PUL-042 turns out to be a drug with promising benefits, considering the limited epidemiological evidence available.

\section{CONCLUSION}

The nasopharynx is the area with the highest SARS-CoV-2 concentration, which would explain the high spread of the virus. The use of mouthwashes and 
nasal sprays, that reduce the SARS-CoV-2 viral load in the nasopharyngeal area, could help to prevent or decrease the spread, while other treatments and vaccines are being developed. The evidence presents multiple substances with antiviral capacity and apparent safety for use in mucosas, including povidone-iodine, hydrogen peroxide, cyclodextrins, and the synthetic drug PUL-042. At present, there is no clinical evidence of the effectiveness and safety of these substances against the SARS-CoV-2 spread. However, there are ongoing clinical trials to verify it, and thus, be able to generate methods to prevent or decrease its expansion among the population.

SANTOS-LÓPEZ, M.; JAQUE, D.; FUENTES, E. \& GONZÁLEZ-QUINTANILLA, D. Enjuagues bucales y aerosoles nasales como un método de prevenir la propagación de SARS-CoV-2. Int. J. Odontostomat., 14(4):513-518, 2020.

RESUMEN: La pandemia de COVID-19 ha infectado a millones de personas en el mundo. Su extremadamente alta capacidad de propagación se debe a la gran acumulación en la región nasofaríngea y su transmisión vía fluidos respiratorios.Considerando el tiempo necesario para desarrollar vacunas y tratamientos, se vuelve fundamental la investigación de métodos preventivos como el uso de enjuague bucal y spray nasal, que puedan disminuir la carga viral en la zona nasofaríngea y así también la capacidad de propagación de SARS-CoV-2La evidencia presenta compuestos con capacidad antiviral como la povidona iodada, peróxido de hidrógeno, ciclodextrinas y la droga sintética PUL-042, que podrían ser usados para dicho propósito. Actualmente no existe evidencia clínica que demuestre la efectividad de estas sustancias contra SARS-Cov-2, sin embargo, se están desarrollando estudios clínicos para probarlos y generar métodos que ayuden a disminuir o prevenir su transmisión en la población, y así detener esta pandemia.

PALABRAS CLAVE: SARS-CoV-2, COVID-19, enjuague bucal, aerosol nasal, prevención.

\section{REFERENCES}

Amanat, F. \& Krammer, F. SARS-CoV-2 vaccines: status report. Immunity, 52(4):583-9, 2020.

Broom, C. \& Scott, B. The use of PUL-042 inhalation solution to reduce the severity of COVID-19 in adults positive for SARSCoV-2 infection. ClinicalTrials.gov, U.S. National Library of Medicine, 2020. Available from: https://www.clinicaltrials.gov/ ct2/show/NCT04312997

Cao, B.; Wang, Y.; Wen, D.; Liu, W.; Wang, J.; Fan, G.; Ruan, L.; Song, B.; Cai, Y.; Wei, M.; et al. A trial of Lopinavir-Ritonavir in adults hospitalized with severe Covid-19. N. Engl. J. Med., 382(19):1787-99, 2020.
Carrouel, F.; Viennot, S.; Ottolenghi, L.; Gaillard, C. \& Bourgeois, D. Nanoparticles as anti-microbial, anti-inflammatory, and remineralizing agents in oral care cosmetics: a review of the current situation. Nanomaterials (Basel), 10(1):140, 2020.

Caruso, A. A.; Del Prete, A.; Lazzarino, A. I.; Capaldi, R. \& Grumetto, L. May hydrogen peroxide reduce the hospitalization rate and complications of SARS-CoV-2 infection? Infect. Control Hosp. Epidemiol., 1-5, 2020. DOI: https://www.doi.org/10.1017/ice.2020.170

Chan, J. F. W.; Yuan, S.; Kok, K. H.; To, K. K. W.; Chu, H.; Yang, J.; Xing, F.; Liu, J.; Yip, C. C. Y.; Poon, R. W. S.; et al. A familial cluster of pneumonia associated with the 2019 novel Coronavirus indicating person-to-person transmission: a study of a family cluster. Lancet, 395(10223):514-23, 2020.

Cheng, Z. J. \& Shan, J. 2019 novel coronavirus: where we are and what we know. Infection, 48(2):155-63, 2020.

Chu, H.; Chan, J. F. W.; Yuen, T. T. T.; Shuai, H.; Yuan, S.; Wang, Y.; Hu, B.; Yip, C. C. Y.; Tsang, J. O. L.; Huang, X.; et al. Comparative tropism, replication kinetics, and cell damage profiling of SARS-CoV-2 and SARS-CoV with implications for clinical manifestations, transmissibility, and laboratory studies of COVID-19: an observational study. Lancet Microbe, 1(1):E14-E23, 2020. DOI: https://www.doi.org/ 10.1016/S2666-5247(20)30004-5

Eggers, M.; Eickmann, M. \& Zorn, J. Rapid and effective virucidal activity of povidone-iodine products against Middle East Respiratory Syndrome Coronavirus (MERS-CoV) and Modified Vaccinia Virus Ankara (MVA). Infect. Dis. Ther., 4(4):491-501, 2015.

Eggers, M.; Koburger-Janssen, T.; Eickmann, M. \& Zorn, J. In vitro bactericidal and virucidal efficacy of povidone-iodine gargle/mouthwash against respiratory and oral tract pathogens. Infect. Dis. Ther., 7(2):249-59, 2018.

Felsenstein, S.; Herbert, J. A.; McNamara, P. S. \& Hedrich, C. M. COVID-19: immunology and treatment options. Clin. Immunol., 215:108448, 2020. DOI: https://www.doi.org/ 10.1016/j.clim.2020.108448

Finnegan, M.; Linley, E.; Denyer, S. P.; McDonnell, G.; Simons, C. \& Maillard, J. Y. Mode of action of hydrogen peroxide and other oxidizing agents: differences between liquid and gas forms. J. Antimicrob. Chemother., 65(10):2108-15, 2010.

Gautret, P.; Lagier, J. C.; Parola, P.; Hoang, V. T.; Meddeb, L.; Sevestre, J.; Mailhe, M.; Doudier, B.; Aubry, C.; Amrane, S.; et al. Clinical and microbiological effect of a combination of hydroxychloroquine and azithromycin in 80 COVID-19 patients with at least a six-day follow up: a pilot observational study. Travel Med. Infect. Dis., 34:101663, 2020. DOI: https:/ /www.doi.org/10.1016/j.tmaid.2020.101663

González-Quintanilla, D. \& Santos-López, M. Preventive measures and considerations for oral surgery practice during COVID-19. Int. J. Odontostomat., 14(3):338-41, 2020.

Guan, W. J.; Ni, Z. Y.; Hu, Y.; Liang, W. H.; Ou, C. Q.; He, J. X.; Liu, L.; Shan, H.; Lei, C. L.; Hui, D. S. C.; et al. Clinical characteristics of Coronavirus Disease 2019 in China. N. Engl. J. Med., 382:1708-20, 2020.

Hoffmann, M.; Kleine-Weber, H.; Schroeder, S.; Krüger, N.; Herrler, T.; Erichsen, S.; Schiergerns, T. S.; Herrler, G.; Wu, N. H.; Nitsche, A.; et al. SARS-CoV-2 cell entry depends on ACE2 and TMPRSS2 and is blocked by a clinically proven protease inhibitor. Cell, 181(2):271-80.e8, 2020.

Huang, C.; Wang, Y.; Li, X.; Ren, L.; Zhao, J.; Hu, Y.; Zhang, L.; Fan, G.; Xu, J.; Gu, X.; et al. Clinical features of patients infected with 2019 novel coronavirus in Wuhan, China. Lancet, 395(10223):497-506, 2020. 
SANTOS-LÓPEZ, M.; JAQUE, D.; FUENTES, E. \& GONZÁLEZ-QUINTANILLA, D. Mouthwashes and nasal sprays as a way to prevent the spread of SARS-CoV-2. Int. J. Odontostomat., 14(4):513-518, 2020.

Jambhekar, S. S. \& Breen, P. Cyclodextrins in pharmaceutical formulations I: structure and physicochemical properties, formation of complexes, and types of complex. Drug Discov. Today, 21(2):356-62, 2016.

Jin, Y. H.; Cai, L.; Cheng, Z. S.; Cheng, H.; Deng, T.; Fan, Y. P.; Fang, C.; Huang, D.; Huang, L. Q.; Huang, Q.; et al. A rapid advice guideline for the diagnosis and treatment of 2019 novel coronavirus (2019-nCoV) infected pneumonia (standard version). Mil. Med. Res., 7:4, 2020. DOI: https:// www.doi.org/10.1186/s40779-020-0233-6

Johns Hopkins University \& Medicine. COVID-19 Dashboard by the Center for Systems Science and Engineering (CSSE) at Johns Hopkins University (JHU). Baltimore, Johns Hopkins University \& Medicine, Coronavirus Resource Center, 2020. Available from: https://coronavirus.jhu.edu/ map.html

Kampf, G.; Todt, D.; Pfaender, S. \& Steinmann, E. Persistence of coronaviruses on inanimate surfaces and their inactivation with biocidal agents. J. Hosp. Infect., 104(3):246-51, 2020.

Kariwa, H.; Fujii, N. \& Takashima, I. Inactivation of SARS coronavirus by means of povidone-iodine, physical conditions and chemical reagents. Dermatology, 212 Suppl. 1 (Suppl. 1):119-23, 2006.

Kawana, R.; Kitamura, T.; Nakagomi, O.; Matsumoto, I.; Arita, M.; Yoshihara, N.; Yanagi, K.; Yamada, A.; Morita, O.; Yoshida, Y.; et al. Inactivation of human viruses by povidoneiodine in comparison with other antiseptics. Dermatology, 195 Suppl. 2:29-35, 1997.

Kazmi, S. M. R. A Clinical Trial of Gargling Agents in Reducing Intraoral Viral Load Among COVID-19 Patients (GARGLES). ClinicalTrials.gov, U.S. National Library of Medicine, 2020. Available from: https://clinicaltrials.gov/ct2/show/ NCT04341688

Kejner, A. E. COVID-19: Povidone-lodine Intranasal Prophylaxis in Front-line Healthcare Personnel and Inpatients (PIIPPI). ClinicalTrials.gov, U.S. National Library of Medicine, 2020. Available from: https://clinicaltrials.gov/ct2/show/ NCT04364802

Kirk-Bayley, J.; Sunkaraneni, S. \& Challacombe, S. The use of povidone iodine nasal spray and mouthwash during the current COVID-19 pandemic may reduce cross infection and protect healthcare workers. SSRN, 2020. DOI: http:// www.doi.org/10.2139/ssrn.3563092

Kurkov, S. V. \& Loftsson, T. Cyclodextrins. Int. J. Pharm., 453(1):167-80, 2013.

Lai, C. C.; Shih, T. P.; Ko, W. C.; Tang, H. J. \& Hsueh, P. R. Severe Acute Respiratory Syndrome Coronavirus 2 (SARSCoV-2) and Coronavirus disease-2019 (COVID-19): the epidemic and the challenges. Int. J. Antimicrob. Agents, 55(3):105924, 2020. DOI: https://www.doi.org/10.1016/ j.ijantimicag.2020.105924

Lake, M. A. What We know so far: COVID-19 current clinical knowledge and research. Clin. Med. (Lond.), 20(2):124-7, 2020.

Leiva-Juarez, M. M.; Kirkpatrick, C. T.; Gilbert, B. E.; Scott, B.; Tuvim, M. J.; Dickey, B. F.; Evans, S. E. \& Markesich, D. Combined aerosolized toll-like receptor ligands are an effective therapeutic agent against influenza pneumonia when co-administered with oseltamivir. Eur. J. Pharmacol., 818:191-7, 2018.

Li, Q.; Guan, X.; Wu, P.; Wang, X.; Zhou, L.; Tong, Y.; Ren, R.; Leung, K. S. M.; Lau, E. H. Y.; Wong, J. Y.; et al. Early transmission dynamics in Wuhan, China, of novel coronavirus-infected pneumonia. N. Engl. J. Med., 382:1199-207, 2020.
Lu, R.; Zhao, X.; Li, J.; Niu, P.; Yang, B.; Wu, H.; Wang, W.; Song, H.; Huang, B.; Zhu, N.; et al. Genomic characterisation and epidemiology of 2019 novel coronavirus: implications for virus origins and receptor binding. Lancet, 395(10224):P565-P574, 2020.

Mahase, E. China coronavirus: WHO declares international emergency as death toll exceeds 200. BMJ, 368:m408, 2020. DOI: http://www.doi.org/10.1136/bmj.m408

Meng, L.; Hua, F. \& Bian, Z. Coronavirus Disease 2019 (COVID-19): emerging and future challenges for dental and oral medicine. J. Dent. Res., 12;99(5):481-7, 2020.

Nayak, J. V. \& Vukkadala, N. PVP-I nasal sprays and SARSCoV-2 nasopharyngeal titers (for COVID-19). ClinicalTrials.gov, U.S. National Library of Medicine, 2020. Available from: https://clinicaltrials.gov/ct2/show/ NCT04347954

Pan, Y.; Zhang, D.; Yang, P.; Poon, L. L. M. \& Wang, Q. Viral load of SARS-CoV-2 in clinical samples. Lancet Infect. Dis., 20(4):411-2, 2020.

Perlman, S. Another decade, another coronavirus. N. Engl. J. Med., 382:760-2, 2020.

Phelan, A. L.; Katz, R. \& Gostin, L. O. The novel coronavirus originating in Wuhan, China: challenges for global health governance. JAMA, 2020. DOI: https://www.doi.org/ 10.1001/jama.2020.1097

Pratelli, A. \& Colao, V. Role of the lipid rafts in the life cycle of canine coronavirus. J. Gen. Virol., 96(Pt. 2):331-7, 2015.

Rickert, S. \& Moses, L. Gargling and nasal rinses to reduce oro- and nasopharyngeal viral load in patients with COVID-19. ClinicalTrials.gov, U.S. National Library of Medicine, 2020. Available from: https://clinicaltrials.gov/ ct2/show/NCT04344236

Rothan, H. A. \& Byrareddy, S. N. The epidemiology and pathogenesis of coronavirus disease (COVID-19) outbreak. J. Autoimmun., 109:102433, 2020. DOI: https:/ /www.doi.org/10.1016/j.jaut.2020.102433

Sharma, K.; Acharya, S.; Verma, E.; Singhal, D. \& Singla, N. Efficacy of chlorhexidine, hydrogen peroxide and tulsi extract mouthwash in reducing halitosis using spectrophotometric analysis: A randomized controlled trial. J. Clin. Exp. Dent., 11(5):e457-e463, 2019.

Shi, H.; Han, X.; Jiang, N.; Cao, Y.; Alwalid, O.; Gu, J.; Fan, Y. \& Zheng, C. Radiological findings from 81 patients with COVID-19 pneumonia in Wuhan, China: a descriptive study. Lancet Infect. Dis., 20(4):P425-P434, 2020 Apr. DOI: https:/ /www.doi.org/10.1016/S1473-3099(20)30086-4

Sungnak, W.; Huang, N.; Bécavin, C.; Berg, M.; Queen, R.; Litvinukova, M.; Talavera-López, C.; Maatz, H.; Reichart, D.; Sampaziotis, F.; et al. SARS-CoV-2 entry factors are highly expressed in nasal epithelial cells together with innate immune genes. Nat. Med., 26:681-7, 2020.

Tait, S.; Salvati, A. L.; Desideri, N. \& Fiore, L. Antiviral activity of substituted homoisoflavonoids on enteroviruses. Antiviral Res., 72(3):252-5, 2006.

Tombes, M. B. \& Gallucci, B. The effects of hydrogen peroxide rinses on the normal oral mucosa. Nurs. Res., 42(6):3327, 1993.

Verdecchia, P.; Cavallini, C.; Spanevello, A. \& Angeli, F. The pivotal link between ACE2 deficiency and SARS-CoV-2 infection. Eur. J. Intern. Med., 76:14-20, 2020.

Wan, Y.; Shang, J.; Graham, R.; Baric, R. S. \& Li, F. Receptor recognition by the novel coronavirus from Wuhan: an analysis based on decade-long structural studies of SARS Coronavirus. J. Virol., 94(7):e00127-20, 2020. 
SANTOS-LÓPEZ, M.; JAQUE, D.; FUENTES, E. \& GONZÁLEZ-QUINTANILLA, D. Mouthwashes and nasal sprays as a way to prevent the spread of SARS-CoV-2. Int. J. Odontostomat., 14(4):513-518, 2020.

Wang, D.; Hu, B.; Hu, C.; Zhu, F.; Liu, X.; Zhang, J.; Wang, B.; Xiang, H.; Cheng, Z.; Xiong, Y.; et al. Clinical characteristics of 138 hospitalized patients with 2019 novel coronavirusinfected pneumonia in Wuhan, China. JAMA, 323(11):10619, 2020a.

Wang, M.; Cao, R.; Zhang, L.; Yang, X.; Liu, J.; Xu, M.; Shi, Z.; Hu, Z.; Zhong, W. \& Xiao, G. Remdesivir and chloroquine effectively inhibit the recently emerged novel coronavirus (2019-nCoV) in vitro. Cell Res., 30:269-71, 2020b.

Wu, D.; Wu, T.; Liu, Q. \& Yang, Z. The SARS-CoV-2 outbreak: what we know. Int. J. Infect. Dis., 94:44-8, 2020.

Yuki, K.; Fujiogi, M. \& Koutsogiannaki, S. COVID-19 pathophysiology: A review. Clin. Immunol., 215:108427, 2020. DOI: https://www.doi.org/10.1016/j.clim.2020.108427

Zhang, L. \& Liu, Y. Potential interventions for novel coronavirus in China: a systematic review. J. Med. Virol., 92(5):479-90, 2020.

Zhou, P.; Yang, X. L.; Wang, X. G.; Hu, B.; Zhang, L.; Zhang, W.; Si, H. R.; Zhu, Y. Z.; Li, B.; Huang, C. L.; et al. A pneumonia outbreak associated with a new coronavirus of probable bat origin. Nature, 579(7798):270-3, 2020.

Zhu, N.; Zhang, D.; Wang, W.; Li, X.; Yang, B.; Song, J.; Huang, B.; Shi, W.; Lu, R.; Niu, P.; et al. A novel coronavirus from patients with pneumonia in China, 2019. N. Engl. J. Med., 382(8):727-33, 2020.

Zou, L.; Ruan, F.; Huang, M.; Liang, L.; Huang, H.; Hong, Z.; Yu, J.; Kang, M.; Song, Y.; Xia, J.; et al. SARS-CoV-2 viral load in upper respiratory specimens of infected patients. N. Engl. J. Med., 382(12):1177-9, 2020.
Corresponding author:

Dr. Matías Santos López

Faculty of Dentistry

Universidad Finis Terrae

Santiago

CHILE

Email: m.santos@hotmail.cl

Received : 06-06-2020

Accepted : 08-06-2020 